\title{
Agroecological assessment of Sudan grass cultivars and new hybrid populations of Bashkir selection
}

\author{
R. A. Biktimirov ${ }^{1 凶}$, Z. M. Sharipkulova ${ }^{1}$, A. A. Nizaeva ${ }^{1}$ \\ ${ }^{1}$ Bashkir Research Institute of Agriculture - Subdivision of the Ufa Federal Research Center of the Russian \\ Academy of Sciences, Ufa, Russia \\ ${ }^{凶}$ E-mail: biktimirov.rifx@yandex.ru
}

Abstract. The purpose of research is to evaluate Sudan grass cultivars in terms of phenotypic plasticity and yield stability in changing environmental conditions. Research methods. The article presents the data of the research conducted in conditions of the Cis-Ural steppe of the Bashkortostan Republic in 2016-2019. 12 Sudan grass cultivars and hybrid populations, selected in the Bashkir Research Institute of Agriculture, being of varied ripeness, were studied for yielding capacity, stability, and plasticity. Weather conditions in the years of research on temperature and water regimes were different. That made it possible to evaluate the lines in contrasting conditions of cultivation. Results. The most adaptive varieties for forage cultivation were identified: Demskaya variety and populations 285,318 and 395 with a regression coefficient $b_{i}$ close and equal to one, are characterized as plastic; populations $392,400,446 / 2$ are responsive to better growing conditions and characterized as intensive $-b_{i}>1$. When cultivated for seeds, population 318 is defined as plastic, while Smena, Demskaya, Chishminskaya rannyaya, Yaktash cultivars, populations 276, 285, 392, 446/2 and 395 are responsive to improved growing conditions and identified as intensive. The best populations according to the comprehensive assessment of varieties for dry matter yield, plasticity and stability are: 400 (yield $69.7 \mathrm{c} /$ ha; plasticity - 1.1; stability - 40.5) and 395 (69.2 c/ha; 1.0; 36.4, respectively). Populations 358 (yield $29.6 \mathrm{c} /$ ha; plasticity - 1.0 ; stability -5.2$)$ and $318(28.1 \mathrm{c} / \mathrm{ha} ; 0.9 ; 4.2$, respectively) were recognized as the best Sudan grass cultivars and populations in terms of seed productivity, plasticity and stability, Scientific novelty. The article collects and presents the materials of many years of the study on Sudan grass phenotypic plasticity and stability.

Keywords: sorghum (Sorghum moench), Sudan grass (Sorghum sudanense), yielding capacity, adaptivity, plasticity, stability.

For citation: Biktimirov R. A., Sharipkulova Z. M., Nizaeva A. A. Agroecological assessment of Sudan grass cultivars and new hybrid populations of Bashkir selection // Agrarian Bulletin of the Urals. 2020. No. 10 (201). Pp. 2-7. DOI: ...

Paper submitted: 03.06.2020.

\section{Introduction}

Sudan grass is one of the few crops that fully meet the requirements of adaptive-landscape farming in arid regions [10, p. 56]. The crop can withstand long air and soil droughts. It grows quickly after mowing, has a high and stable yielding capacity, high feeding value, and serves multiple purposes. All these qualities make it indispensable for summer feeding of animals and forage production for winter livestock [1, p. 5], [2, p. 33], [16, p. 5], [24, p. 1563].

Forage crop varieties, being of a sufficiently high potential yield, tend to reduce it significantly in production conditions. This is due to the high responsiveness of the crop to changing agro-climatic growing conditions [2, p. 34], [17, p. 49], [18, p. 29]. In this regard, one of the most important directions in crop selection was to develop cultivars that would combine high yielding capacity, crop quality and resistance to environmental factors at the level of the variety, agrocenosis, agroecosystem [1, p. 31], [2, p. 34], [9, p. 492], [22, p. 11], [13, p. 3].

In recent years, cultivation of Sudan grass in the Republic of Bashkortostan has spread to more northern areas not favorable for its growth. This resulted in new problems in crop selection due to the fact that in some years the cultivars do not mature for seeds $[23$, p. 6]. Therefore, one of the main reasons preventing the expansion of the cultivated land for Sudan grass is the lack of early-matured seeds of highly productive varieties [21, p. 25]. There is an urgent need to study new Sudan grass cultivars and hybrid populations to identify samples that would be characterized by crop stability and high responsiveness to better cultivation conditions [4, p. 550], [5, p. 619], [19, p. 9]. Thus, the efforts of breeders should be aimed at creating environmentally plastic varieties that provide sufficiently high yields in conditions of unstable and sharply changing climatic conditions of the region.

There environmental tests are conducted to find stable and adaptive crop varieties and lines (including fodder crops with higher yields of forage and seed production). They detect cultivar reaction to changing weather conditions, including indicators of phenotypic plasticity and stability [3, p. 149], [11, p. 46], [12, p. 16]. The highest yields of varieties and hybrids in various soil and climatic conditions can be achieved when there is a balance between environmental plasticity and stability $[3$, p. 4$],[14$, p. 16], [15, p. 58].

The research goal is to evaluate Sudan grass cultivars in terms of phenotypic plasticity and yield stability in changing environmental conditions. 


\section{Methods}

The work was done in experimental plots of the Chishminskiy crop-breeding center of the Bashkir Research Institute of Agriculture under the soil and climatic conditions of the CisUral steppe zone of the Bashkortostan Republic in 2016-2019.

The soil cover of the experiment site is represented by typical carbonate chernozems of medium capacity. The soil texture is medium loam, being lighter with depth. The underlying rocks are sandstones and marls that contribute to easy infiltration. Therefore, the lack of precipitation in this zone results in the soil drought. The average humus content in the upper arable layer ranges from 7 to $9 \%$ (according to Tiurin). It is $3.2 \ldots 3.4 \%$ at a depth of $40 \ldots 60 \mathrm{~cm}$. The reaction of the soil solution is close to neutral being 7.1...7.4. The content of total nitrogen is $0.4 \%$ (by Kjeldahl), exchangeable potassium (by Chirikov) and mobile phosphorus (by Chirikov) are $20.5 \mathrm{mg} / 100 \mathrm{~g}$ and $10.2 \mathrm{mg} / 100 \mathrm{~g}$ of dry soil; the calcium content is $35 \mathrm{mg}-\mathrm{EQ} / 100 \mathrm{~g}$ (by Aidinian).

The experiment involved 12 Sudan grass varieties and hybrid populations of selection of the Bashkir Research Institute of Agriculture. Chishminskaya rannyaya was chosen as a standard Sudan grass cultivar released in the Ural region and the Republic of Bashkortostan.

Cultivation methods for Sudan grass are generally accepted for the soil and climatic conditions of the Cis-Ural steppe. In all years of research, the predecessor was spring wheat. The crop was sown on May 25-28, when the soil was warmed to the minimum favorable temperatures for Sudan grass to emerge; the seeding rate was 2.0 million germinated seeds/ha. Seeding was carried out with a central-fill planter SKS-6-10 in rows (the row-width spacing was $15 \mathrm{~cm}$ ). Two-factor experience. The plot area was $18.9 \mathrm{~m}^{2}$, the accounting area to determine the fodder yield $-6.9 \mathrm{~m}^{2}$, seed yield $-8.05 \mathrm{~m}^{2}$. Varieties were placed in a random fashion; the repeatability in experiments is fourfold.

Competitive testing of Sudan grass cultivars and hybrid populations was conducted in accordance with the guidelines of the All-Russian Scientific Research Institute of Fodder named after. V. R. Williams [6], the method of the State Committee for testing of new crop varieties [26] and field experience [25].

Phenotypic plasticity $\left(b_{i}\right)$ and stability $\left(\sigma^{2} d\right)$ were found by the method of S. A. Eberchart, W. A. Rassel, which consists in calculating the coefficient of linear regression (bi) and the mean square deviation from the theoretical regression line $\left(\sigma^{2} d\right),(1966)$ as presented by V. A. Zykin [8]. At the first stage, environmental conditions are evaluated using the $I j$ index: the higher the $I j$ value, the more favorable the conditions are. Then the linear regression coefficient $(b i)$ and the mean square deviation from the theoretical regression line $\left(\sigma^{2} d\right)$ were calculated. Stress tolerance of varieties and populations $\left(Y_{\text {min }}-Y_{\text {max }}\right)$ is an important indicator of adaptivity and phenotypic plasticity, determined by the difference between the minimum and maximum yield in $\mathrm{c} /$ ha. The indicator $\left(\left(Y_{\max }+Y_{\min }\right) / 2\right)$ shows the average yield of the variety (c/ha) in contrasting (stressful and non-stressful) conditions and characterizes the genetic flexibility of the cultivar, its compensatory ability. The higher is this indicator, the higher is the degree of correspondence between the variety genotype and environmental factors. These two in- dicators were calculated using the equations of A. A. Rossille, J. Hamblin as interpreted by A. A. Goncharenko [7, p. 50], the scale of productivity $(d)$ - according to V. A. Zykin [8].

Meteorological conditions in the years of research were unstable during the growing season, which gave an objective assessment of the studied lines based on the prevailing environmental conditions, primarily due to the hydrothermal regime.

In 2016, the average air temperature in the third decade of May was $19.0{ }^{\circ} \mathrm{C}$; the precipitation rate was $13 \%$ of the norm. The temperature in the first third of June was below the norm by $1.2{ }^{\circ} \mathrm{C}$, in the second third it exceeded $2.5^{\circ} \mathrm{C}$. Precipitation rates for month thirds were 47; 22 and $200 \%$ of the norm. In July, the average air temperature and precipitation in thirds were $20.4 ; 21.5 ; 22.4{ }^{\circ} \mathrm{C}$ and $12.2 ; 4.4$ and $1.4 \mathrm{~mm}$, respectively. In August-the average air temperature exceeded the average values by $6.5 ; 8.8$ and $5.1{ }^{\circ} \mathrm{C}$, precipitation rates were $69 ; 73$ and $81 \%$ of the norm.

In 2017 , the last third of May was cool $\left(12.1^{\circ} \mathrm{C}\right)$ and rainy ( $213 \%$ of the norm). The first third of June was cool $\left(11.8^{\circ} \mathrm{C}\right)$, the second - moderately warm $\left(17.3^{\circ} \mathrm{C}\right)$, the third was also characterized by a lack of heat $\left(17.2^{\circ} \mathrm{C}\right)$, precipitation for the thirds were 447; 96 and $115 \%$ of the norm. The average air temperature in July for decades was $17.2 ; 19.3$ and $21.1^{\circ} \mathrm{C}$; precipitation rate was $30.6 ; 15.9$ and $1.2 \mathrm{~mm}$; in August, the air temperature for decades was $20.2 ; 17.2$; and $19.6{ }^{\circ} \mathrm{C}$ and the amount of precipitation was $24.1 ; 4.8$ and $9.1 \mathrm{~mm}$, respectively.

In 2018, the third decade of May was rainy (154\% of the norm) and warm $\left(14.7^{\circ} \mathrm{C}\right)$. The first two decades of June were $\operatorname{cool}\left(12.4\right.$ and $15.6{ }^{\circ} \mathrm{C}$, which is 4.4 and $2.1{ }^{\circ} \mathrm{C}$ below the average annual data), the third decade was warm $\left(21.1^{\circ} \mathrm{C}\right)$, precipitation for the decades was $16.6 ; 6.5$ and $35 \%$ of the norm. The average temperature in July for decades was $22.4 ; 21.2$ and $20.6{ }^{\circ} \mathrm{C}$, which was higher than the norm by $3.1 ; 1.8$ and $1.9^{\circ} \mathrm{C}$, precipitation was $6.7 ; 12.8$ and $0.0 \mathrm{~mm}$. The average temperature in August for decades was at the average annual level being 20.3 ; 17.9 ; and $16.2^{\circ} \mathrm{C}$, precipitation rate was 83 ; 53 and $79 \%$ of the norm.

In 2019, the third decade of May was warm $\left(14.6{ }^{\circ} \mathrm{C}\right)$ and wet $(24.1 \mathrm{~mm})$. The air temperature for decades in June was 16,$5 ; 16.4$; and $19.4{ }^{\circ} \mathrm{C}$ or $-0.3 ;-1.3$ and $+1.3{ }^{\circ} \mathrm{C}$ of the norm, precipitation was $183.3 ; 22.1$ and $32.0 \%$ of the average annual values. In July, the first decade was cool being $17.9^{\circ} \mathrm{C}\left(-1.4^{\circ} \mathrm{C}\right)$; the second one was warm $\left(+1.8^{\circ} \mathrm{C}\right)$, and the third decade was within the norm; precipitation for decades was $148.3 ; 40$ and $13 \%$ of the norm. The first decade of August was cold, the second-warm, the third $-\operatorname{cool}(-3,3 ;+1,4$ and $-1,7{ }^{\circ} \mathrm{C}$ of the norm), precipitation for the decades was 298,$7 ; 114$ and $66 \%$ of the norm. In the first decade of September, the air temperature was below the norm by $2.0^{\circ} \mathrm{C}$, the second decade was moderately warm $\left(+0.7^{\circ} \mathrm{C}\right)$; precipitation for decades was $26.8 ; 167 \%$ of the norm.

Summing up the general characteristics of the soil and climatic conditions of the Cis-Ural steppe zone of the Republic of Bashkortostan and in particular the Chishminskiy plant breeding center, where the research was carried out, it can be concluded that they are typical for the steppe zone. They meet the basic biological requirements of Sudan grass and are quite 
suitable to get high and stable yields of green mass, hay and seeds. This conclusion is based on the growing season length of 137 days with an average daily air temperature of more than plus $10^{\circ} \mathrm{C}$ and the sum of active temperatures being $2230{ }^{\circ} \mathrm{C}$. It takes an average of $1800^{\circ} \mathrm{C}$ to produce high yields of conditioned Sudan grass seeds or from 1600 to $2200{ }^{\circ} \mathrm{C}$ depending on the cultivar ripeness. The Republic of Bashkortostan and other regions of the southern Urals have enough warm days to cultivate early-maturing varieties of such a heat-loving crop as Sudan grass. Early-maturing and mid-early Sudan grass varieties with a growing period of 85-100 days provide two mowings of green mass, as well as develop a high yield of conditioned seeds.

Statistical processing of the obtained data was performed using the variance analysis method with the add-in program CXSTAT for Microsoft Excel and the package of programs AGROS 2.09 for statistical and biometric-genetic analysis in crop production and selection.

\section{Results}

According to the period from "full sprouts" to "waxy ripeness of seeds", the studied Sudan grass varieties can be divided into three groups (in accordance with the climatic conditions of the research site): short-season - Chishminskaya rannyaya (80.3 days); middle-early (83.5-84.3 days) and mid-season (88.5-90.3 days) (table 1$)$.

There has been found high potential of individual Sudan grass cultivars for collecting dry matter and seed productivity. The highest yield of dry matter was established in the hybrid population 446/2 in 2016 (88.8 c/ha) and 400 in 2017 (88.0 $\mathrm{c} / \mathrm{ha}$ ). The highest average yield over a four-year period was observed in the populations of the mid-season groups $446 / 2$ (72.7 c/ha) and $392(72.5 \mathrm{c} / \mathrm{ha})$. The yield of these populations exceeded the standard by 24 and $25 \%$, respectively. Short-season and middle-early numbers had lower yields. Sudan grass cultivars had a high potential for seed productivity. The hybrid population 358 had the highest seed yield in 2019 (36.0 c/ha) and the hybrid population 276 in 2016 (34.5 c/ha). On average, over 4 years of the research, the highest productivity was shown by hybrid populations of the middle-early group: 276 (30.4 c/ha) and 358 (29.6 c/ha). Their seed yield exceeded the standard by 17 and $14 \%$, respectively (table 2 ).

The yield stability depends much on the yield scope $(d)$. The lower the latter is, the more stable the productivity is in specific soil and climatic conditions. Its lowest value in terms of dry matter yield was observed in the hybrid population 358 $(33.5 \%)$, and in terms of seed productivity in hybrid populations 318 and 395 (15.7 and $16.9 \%$ ),

An important indicator of the cultivar stability to the stressful environment under changing meteorological conditions of cultivation is their adaptivity (or stress tolerance). It is determined by the difference between the minimum and maximum yield value $\left(Y_{\min }-Y_{\max }\right)$. The adaptivity index has a negative value. The lower it is, the higher the stress tolerance of the variety. The range of adaptive capabilities is more widely represented in the variety. The most stress-tolerant Sudan grass hybrid populations in terms of dry matter yield were 400 and $446 / 2(-44.5 \ldots-44.2$, respectively), as to seed productivity, the most stress-resistant variety was Demskaya (-13.1).

Stress tolerance of varieties can be supplemented by the indicator of genetic flexibility $\left(Y_{\max }+Y_{\min }\right) / 2$. It shows the degree of correspondence between the genotypic capabilities of the variety and varied environmental factors [7, p. 50]. Among the studied numbers of Sudan grass, its value (in terms of dry matter yield) was highest in hybrid populations 446/2 (66.7) and 400 (65.7). The indicator of genetic flexibility when using Sudan grass varieties for seeds was highest in hybrid populations 358 and 276 (30.5 and 30.6, respectively). They demonstrate a strong correspondence between the cultivar genotype and environmental factors. The Yaktash variety had the lowest indicators of dry matter yield (53.8), the hybrid population 392 was of lower seed productivity (20.5).

The environmental condition index $(I j)$ determines the variability of growing conditions and can take either a positive or a negative value. The most favorable conditions are formed in years with a positive index sign, the worst - with a negative one. During the research years, the index of environmental conditions of Sudan grass numbers in terms of dry matter yield varied from 9.4 to -23 , and in terms of seed productivity from 1.6 to -1.9 . The best conditions for the genetic potential of cultivars were formed in 2016 and 2017, where the environment index had the highest positive values $I j=1.6$ and 9.4 (table 3).

Table 1

Growing period of Sudan grass varieties, days (2016-2019)

\begin{tabular}{|c|c|c|c|c|c|}
\hline \multirow{2}{*}{ Breed, hybrid population } & \multicolumn{4}{|c|}{ Year } & \multirow{2}{*}{ Average } \\
\hline & 2016 & 2017 & 2018 & 2019 & \\
\hline \multicolumn{6}{|c|}{ Short-season group } \\
\hline Chishminskaya rannyaya (St.) & 71 & 89 & 76 & 85 & 80,3 \\
\hline \multicolumn{6}{|c|}{ Middle-early group } \\
\hline Yaktash & 72 & 91 & 80 & 91 & 83,5 \\
\hline Smena & 73 & 91 & 79 & 92 & 83,8 \\
\hline Demskaya & 72 & 92 & 80 & 92 & 84 \\
\hline Population 276 & 71 & 93 & 79 & 90 & 83,3 \\
\hline Population 285 & 73 & 92 & 80 & 92 & 84,3 \\
\hline Population 318 & 73 & 93 & 79 & 92 & 84,3 \\
\hline Population 358 & 74 & 90 & 79 & 91 & 83,5 \\
\hline \multicolumn{6}{|c|}{ Mid-season group } \\
\hline Population 392 & 81 & 94 & 82 & 100 & 89,3 \\
\hline Population 400 & 82 & 94 & 83 & 102 & 90,3 \\
\hline Population 446/2 & 81 & 95 & 83 & 100 & 89,8 \\
\hline Population 395 & 81 & 93 & 80 & 100 & 88,5 \\
\hline
\end{tabular}


Table 2

The adaptive potential of Sudan grass varieties, 2016-2019

\begin{tabular}{|c|c|c|c|c|c|c|}
\hline \multirow{2}{*}{ Breed, hybrid population } & \multicolumn{3}{|c|}{ The yield of dry matter, c/ha } & \multirow{2}{*}{ The yield scope, \% } & \multirow{2}{*}{$\begin{array}{l}\text { Stress tolerance } \\
\left(Y_{\min }-Y_{\max }\right), \mathrm{c} / \mathrm{ha}\end{array}$} & \multirow{2}{*}{$\begin{array}{c}\text { Genetic flexibility } \\
\left(Y_{\max }+Y_{\min }\right) / 2, c / h a\end{array}$} \\
\hline & $\operatorname{Max}$ & Min & Average & & & \\
\hline \multicolumn{7}{|c|}{ By dry matter yield } \\
\hline Chishminskaya rannyaya (St.) & 69.3 & 39.9 & 58.1 & 42.5 & -29.4 & 54.6 \\
\hline Yaktash & 69.8 & 37.8 & 59.0 & 45.9 & -32.0 & 53.8 \\
\hline Smena & 70.3 & 38.6 & 59.0 & 45.2 & -31.7 & 54.4 \\
\hline Demskaya & 76.6 & 46.6 & 68.9 & 39.2 & -29.9 & 61.6 \\
\hline Population 276 & 77.6 & 44.9 & 65.7 & 42.2 & -32.7 & 61.2 \\
\hline Population 285 & 75.2 & 43.9 & 66.3 & 42.0 & -31.3 & 59.5 \\
\hline Population 318 & 76.0 & 43.4 & 67.3 & 42.9 & -32.6 & 59.9 \\
\hline Population 358 & 75.6 & 50.3 & 68.0 & 33.5 & -25.3 & 62.9 \\
\hline Population 392 & 85.5 & 42.9 & 72.5 & 49.9 & -42.6 & 64.2 \\
\hline Population 400 & 88.0 & 43.5 & 69.7 & 50.6 & -44.5 & 65.7 \\
\hline Population 446/2 & 88.8 & 44.6 & 72.7 & 49.8 & -44.2 & 66.7 \\
\hline Population 395 & 78.4 & 45.0 & 69.2 & 42.7 & -33.4 & 61.7 \\
\hline \multicolumn{7}{|c|}{ By seed productivity } \\
\hline Chishminskaya rannyaya (St.) & 31.1 & 20.8 & 26.0 & 33.1 & -10.3 & 25.9 \\
\hline Yaktash & 31.3 & 21.8 & 25.2 & 30.4 & -9.5 & 26.5 \\
\hline Smena & 31.0 & 20.8 & 25.5 & 32.9 & -10.2 & 25.9 \\
\hline Demskaya & 33.7 & 20.6 & 27.5 & 38.9 & -13.1 & 27.1 \\
\hline Population 276 & 34.5 & 26.8 & 30.4 & 22.3 & -7.7 & 30.6 \\
\hline Population 285 & 31.5 & 24.4 & 28.5 & 22.5 & -7.1 & 27.9 \\
\hline Population 318 & 31.3 & 26.4 & 28.1 & 15.7 & -4.9 & 28.8 \\
\hline Population 358 & 36.0 & 25.1 & 29.6 & 30.3 & -10.9 & 30.5 \\
\hline Population 392 & 25.4 & 15.7 & 21.9 & 38.2 & -9.7 & 20.5 \\
\hline Population 400 & 27.4 & 19.2 & 22.6 & 29.9 & -8.2 & 23.3 \\
\hline Population 446/2 & 26.8 & 19.7 & 23.8 & 26.5 & -7.1 & 23.2 \\
\hline Population 395 & 28.0 & 23.3 & 25.2 & 16.9 & -4.7 & 25.6 \\
\hline
\end{tabular}

Table 3

Productivity, phenotypic plasticity and stability of Sudan grass varieties

\begin{tabular}{|c|c|c|c|c|c|c|c|}
\hline \multirow{2}{*}{ Breed, hybrid population } & \multicolumn{5}{|c|}{ Yield, c/ha } & \multirow{2}{*}{ Plasticity, $b_{i}$} & \multirow{2}{*}{$\begin{array}{l}\text { Stability, } \\
\sigma^{2} d, c / h a\end{array}$} \\
\hline & 2016 & 2017 & 2018 & 2019 & Average & & \\
\hline \multicolumn{8}{|c|}{ Dry matter } \\
\hline Chishminskaya rannyaya (St.) & 69.3 & 61.1 & 62.2 & 39.9 & 58.1 & 0.8 & 30.5 \\
\hline Yaktash & 69.8 & 64.8 & 63.5 & 37.8 & 59.0 & 0.9 & 29.0 \\
\hline Smena & 70.3 & 63.8 & 63.4 & 38.6 & 59.0 & 0.9 & 29.0 \\
\hline Demskaya & 75.8 & 76.6 & 76.5 & 46.6 & 68.9 & 1.0 & 45.7 \\
\hline Population 276 & 77.6 & 74.4 & 66.0 & 44.9 & 65.7 & 0.9 & 28.9 \\
\hline Population 285 & 75.2 & 72.1 & 74.0 & 43.9 & 66.3 & 1.0 & 45.7 \\
\hline Population 318 & 75.3 & 74.8 & 76.0 & 43.4 & 67.3 & 1.0 & 45.7 \\
\hline Population 358 & 70.8 & 75.6 & 75.2 & 50.3 & 68.0 & 0,7 & 18.9 \\
\hline Population 392 & 84.8 & 85.5 & 76.9 & 42. & 72.5 & 1.3 & 59.5 \\
\hline Population 400 & 73.3 & 88.0 & 74.0 & 43.5 & 69.7 & 1.1 & 40.5 \\
\hline Population 446/2 & 88.8 & 82.4 & 75.2 & 44.6 & 72.7 & 1.3 & 60.3 \\
\hline Population 395 & 78,4 & 76.6 & 76.6 & 45.0 & 69.2 & 1.0 & 36.4 \\
\hline$I j$ & 9.4 & 8.4 & 5.2 & -23 & - & - & - \\
\hline $\mathrm{HCP}_{05}$ & 6.24 & 9.01 & 9.63 & 6.92 & - & - & - \\
\hline \multicolumn{8}{|c|}{ Seeds' } \\
\hline Chishminskaya rannyaya (St.) & 28.0 & 20.8 & 24.1 & 31.1 & 26.0 & 1.2 & 9.6 \\
\hline Yaktash & 31.3 & 22.5 & 25.1 & 21.8 & 25.2 & 1.2 & 7.5 \\
\hline Smena & 31.0 & 25.6 & 24.7 & 20.8 & 25.5 & 1.7 & 14.8 \\
\hline Demskaya & 28.9 & 33.7 & 26.9 & 20.6 & 27.5 & 2.5 & 32.9 \\
\hline Population 276 & 34.5 & 31.7 & 26.8 & 28.8 & 30.4 & 1.6 & 13.3 \\
\hline Population 285 & 30.7 & 31.5 & 24.4 & 27.2 & 28.5 & 1.5 & 11.9 \\
\hline Population 318 & 31.3 & 28.0 & 26.4 & 26.7 & 28.1 & 1.0 & 5.2 \\
\hline Population 358 & 25.5 & 31.9 & 25.1 & 36.0 & 29.6 & 0.9 & 4.2 \\
\hline Population 392 & 23.2 & 25.4 & 23.4 & 15.7 & 21.9 & 1.6 & 13.2 \\
\hline Population 400 & 19.2 & 27.4 & 23.8 & 20.0 & 22.6 & 0.5 & 1.3 \\
\hline Population $446 / 2$ & 25.5 & 26.8 & 23.2 & 19.7 & 23.8 & 1.5 & 11.9 \\
\hline Population 395 & 24.8 & 28.0 & 24.6 & 23.3 & 25.2 & 1.4 & 10.0 \\
\hline Ij & 1.6 & 1.6 & -1.3 & -1.9 & - & - & - \\
\hline$H C P_{05}$ & 3.48 & 3.39 & 4.52 & 5.61 & - & - & - \\
\hline
\end{tabular}


According to S. A. Eberhart, W. A. Russell, plasticity is a positive response of the genotype to improved growing conditions. As a parameter for evaluating this response, they proposed the calculation of a linear regression coefficient, which can be greater than (high responsiveness) and less than (weak responsiveness) unit, as well as equal to one (changes in yield fully correspond to changes in conditions).

In our experience, the highest responsiveness to better growing conditions $\left(b_{i}>1\right)$ was observed in Sudan grass hybrid populations $392,400,446 / 2$ in terms of dry matter yield, and in terms of seed productivity in varieties Smena, Demskaya, Chishminskaya rannyaya, Yaktash and hybrid populations 276, 285, 392, 446/2 and 395. All these varieties of intensive type, develop high yields in optimal soil and climatic conditions. However, their productivity decreases sharply under unfavorable conditions or poor farming practices.

Chishminskaya rannyaya, Yaktash, Smena varieties and hybrid populations 276 and 358 had a plasticity coefficient lower than one $\left(b_{i}<1\right)$ in terms of dry matter yield. Hybrid populations 358 and 400 had a similar coefficient in seed productivity. These cultivars have a genotypic potential that is characterized by low responsiveness to changes in farming practices. They are best grown on an extensive background, where they can provide the greatest return at the lowest cost.

The Demskaya variety and hybrid populations 285, 318 and 395 had coefficient of plasticity equal to or close to one $\left(b_{i}=1\right)$ in terms of dry matter yield, the hybrid population 318 had the same index in seed productivity. These numbers have the highest correspondence of changes in yield to changes in growing conditions.

Following the model of S. A. Eberhart and W. A. Rassell, the varieties that have plasticity $\left(b_{i}\right)$ close to 1 , and the insignificant stability index $\left(\sigma^{2} d\right)$ should be considered as the most valuable in breeding and practical terms. These cultivars, along with a high stable yield, have high responsiveness to improved conditions, which is typical for intensive type varieties. According to the results of the research, the following numbers of Sudan grass can be attributed to them: Yaktash, Smena, hybrid populations 276 and 395 (by dry matter yield) and hybrid populations 318 and 358 (by seed productivity). Among the varieties presented in the studies, the most stable in dry matter yield were hybrid populations 358 and $276\left(\sigma^{2} d=18.9\right.$ and 28.9 , respectively), and in seed productivity hybrid populations 400,358 , and $392\left(\sigma^{2} d=1.3 ; 4.2\right.$ and 5.2 , respectively). Hybrid populations $446 / 2$ and $392\left(\sigma^{2} d=60.3\right.$ and 59.5) were the most unstable in terms of dry matter yield, while varieties Demskaya and Smena $\left(\sigma^{2} d=32.9\right.$ and 14.8$)$ were the most unstable in terms of seed productivity. Cultivars of plasticity (bi) less than 1 , regardless of the stability index value $\left(\sigma^{2} d\right)$, should be considered as unpromising, since they lack an important biological and economic feature as an adequate response to improving growing conditions.

\section{Discussion and Conclusion}

The most perspective for breeding and farming practice are cultivars of phenotypic plasticity to get high yields under favorable cultivation conditions. It depicts their high responsiveness to better conditions. They slightly reduce productivity in stressful conditions, that shows the stability of genotypes in adverse conditions. The conducted research on the analysis of phenotypic plasticity and stability made it possible to identify the most adaptive varieties when cultivating them for food in the Republic of Bashkortostan. Demskaya variety and hybrid populations 285,318 and 395 with a plasticity coefficient $b_{i}$ close to and equal to one, are characterized as plastic; hybrid populations $392,400,446 / 2$ are responsive to improved growing conditions and are characterized as intensive $-b_{i}>1$. When cultivated for seeds, population 318 is defined as plastic, while Smena, Demskaya, Chishminskaya rannyaya, Yaktash cultivars, populations 276, 285, 392, 446/2 and 395 are responsive to improved growing conditions and identified as intensive.

Based on a comprehensive assessment of varieties by the value of the average yield of dry matter, phenotypic plasticity and stability, the best numbers are recognized as populations 400 (yield $69.7 \mathrm{c} / \mathrm{ha}$; plasticity -1.1 ; stability -40.5 ) and 395 (69.2 c/ha; $1.0 ; 36.4$, respectively). When cultivating seeds for yield, plasticity and stability, populations 358 (yield $29.6 \mathrm{c} / \mathrm{ha}$; plasticity -1.0 ; stability -5.2$)$ and $318(28.1 \mathrm{c} / \mathrm{ha} ; 0.9 ; 4.2$, respectively) were distinguished. Thus, the new Sudan grass hybrid populations have an advantage in productivity compared to previous varieties and numbers regardless of weather conditions.

\section{References}

1. Kadyrov S. V. Sorgo v TsChR [Sorghum in the Central black soil region]. Rostov-on-Don: Rostizdat, 2008. 80 p. (In Russian.)

2. Kashevarov N. I., Polyudina R. I., Balykina N. V., Shtaus A. P. Sudanka v kormoproizvodstve Sibiri [Sudan grass in forage production in Siberia]. Novosibirsk, 2004. 224 p. (In Russian.)

3. Fasahat P., Rajabi A., Mahmoudi S. B., Noghabi M. A., Rad J. M. An Overview on the Use of Stability Parameters in Plant Breeding // Biometrics \& Biostatistics International Journal. 2015. Vol. 2. No. 5. Pp. 149-159.

4. Potanin V. G., Aleynikov A. F., Stepochkin P. I. Novyy podkhod k otsenke ekologicheskoy plastichnosti sortov rasteniy [Anew approach to assessing the ecological plasticity of plant varieties] // Vavilov's Journal of Genetics and Breeding. 2014. Vol. 18. No. 3. Pp. 548-552. (In Russian.)

5. Rybas I. A. Povyshenie adaptivnosti v selektsii zernovykh kul'tur (obzor) [Improving adaptivity in breeding grain crops (review)] // Agricultural biology. 2016. Vol. 51. No. 5. Pp. 617-626. (In Russian.)

6. Novoselov Yu. K., Kharkov G. D., Shekhovtsova N. S. Metodicheskie ukazaniya po provedeniyu polevykh opytov s kormovymi kul'turami [Methodical instructions for conducting field experiments with forage crops]. Moscow: Podrazdelenie operativnoy poligrafii VIK, 1983. 198 p. (In Russian.)

7. Goncharenko A. A. Ob adaptivnosti i ekologicheskoy ustoichivosti sortov zernovykh kul'tur [On adaptivity and ecological stability of grain varieties] // Bulletin of the Russian Academy of Agricultural Sciences. 2005. No. 6. Pp. 49-53. (In Russian.) 8. Zykin V. A., Belan I. A., Yusov V. S. Metodika rascheta i otsenki parametrov ekologicheskoy plastichnosti sel'skokhoziaistvennykh rasteniy [Method of calculation and evaluation of crop phenotypic plasticity]. Ufa: BashGAU, 2005. 100 p. (In Russian.) 
9. Dragavtsev V. A., Mikhailenko I. M., Proskuriakov M. A. Nekanonicheskiy podkhod k resheniyu zadachi nasledstvennogo povysheniya zasukhoustoichivosti u rasteniy [Non-Canonical approach to solving the problem of hereditary increase of drought tolerance in plants] // Agricultural biology. 2017. Vol. 52. No. 3. Pp. 487-500. (In Russian.)

10. Kovtunova N. A., Shishova E. A., Romanyukin A. E., Kovtunov V. V., Sukhenko N. N. Urozhainost' obraztsov sudanskoy travy razlichnogo ekologo-geograficheskogo proiskhozhdeniya [Productivity of Sudan grass samples of different ecological and geographical origin] // Grain Economy of Russia. 2018. No. 1. Pp. 56-61. (In Russian.)

11. Biktimirov R. A., Shakirzyanov A. Kh., Nizaeva A. A. Ekologicheskaya stabilnost' i plastichnost' kormovogo sorgo v Respublike Bashkortostan [Ecological stability and plasticity of forage sorghum in the Republic of Bashkortostan] // Achievements of Science and Technology of AIC. 2019. Vol. 33. No. 8. Pp. 46-49. (In Russian.)

12. Telichko O. N., Mokhan O. V. Ekologicheskaya plastichnost' i stabilnost' sortoobraztsov viki yarovoy [Phenotypic plasticity and stability of spring vetch varieties] // Grain Economy of Russia. 2016. No. 3. Pp. 16-20. (In Russian.)

13. Rybas I. A., Marchenko D. M., Nekrasov E. I., Ivanisov M. M., Grichanikova T. A., Romanyukina I. V. Otsenka parametrov adaptivnosti sortov ozimoy myagkoy pshenitsy [Estimation of adaptivity parameters of soft winter wheat varieties] // Grain Economy of Russia. 2018. No. 4. Pp. 51-54. (In Russian.)

14. Levakova O. V. Rezultaty izucheniya adaptivno-ekologicheskikh pokazateley novykh sortov i perspektivnykh liniy ozimoy myagkoy pshenitsy v usloviyakh Ryazanskoi oblasti [Results of studying adaptive and ecological indicators of new varieties and perspective lines of soft winter wheat in the conditions of the Ryazan region] // Grain Economy of Russia. 2019. No. 2. Pp. 13-16. (In Russian.)

15. Ignatyev S. A., Regidin A. A. Otsenka parametrov adaptivnosti kollektsionnykh obraztsov espartseta [Estimation of adaptivity parameters of collection samples of sainfoin] // Grain Economy of Russia. 2019. No. 3. Pp. 53-58. (In Russian.)

16. Kibal'nik O. P., Efremova I. G., Semin D. S., Gorbunov V. S., Kameneva O. B., Starchak V. I., Kukoleva S. S. Otsenka kachestva zerna i biomassy sorgo s tsel'yu ispol'zovaniya v kormoproizvodstve [Evaluation of the grain quality and sorghum biomass for forage production] // Grain Economy of Russia. 2019. No. 4. Pp. 3-7. (In Russian)

17. Kovtunova N. A. Biologicheskie osobennosti rosta i razvitiya sudanskoy travy [Biological features of Sudan grass growth and development] // Achievements of Science and Technology of AIC. 2016. Vol. 30. No. 6. Pp. 48-51. (In Russian.)

18. Morozov E. V., Vertikova E. A. Izuchenie perspektivnykh liniy sudanskoy travy po kompleksu khoziaistvenno-tsennykh priznakov v usloviyakh Nizhnego Povolzh'ya [Study of perspective Sudan grass lines on a complex of economic and valuable signs in the conditions of the Lower Volga region] // Agrarian Bulletin of the Urals. 2015. No. 4. Pp. 28-32. (In Russian.)

19. Kukoleva S. S., Semin D. S., Kibal'nik O. P., Starchak V. I. Skrining sortoobraztsov sudanskoy travy v usloviyakh Saratovskoy oblasti [Screening of Sudan grass cultivars in the conditions of the Saratov region] // Grain Economy of Russia. 2016. No. 4. Pp. 8-11. (In Russian.)

20. Ermolina G. M., Kovtunova N. A., Romanyukin A. E., Shishova E. A. Regionalnye osobennosti selektsii sudanskoy travy [Regional features of Sudan grass breeding] // Agrarian Bulletin of the Urals. 2017. No. 4 (158). Pp. 16-20. (In Russian.)

21. Shukis E. R., Shukis S. K. Sovershenstvovanie sortovogo sostava sudanskoy travy v Altayskom krae [Improving the varietal composition of Sudan grass in the Altai territory] // Bulletin of the Altai State Agrarian University. 2017. No. 8 (154). Pp. 23-27. (In Russian.)

22. Vertikova E. A., Zhuzhukin V. I., Kukoleva S. S. Izuchenie iskhodnogo materiala dlya selektsii sudanskoy travy v usloviyakh Nizhnego Povolzh'ya [Study of initial material for breeding Sudan grass in the Lower Volga region] // Agrarian scientific journal. 2017. No. 12. Pp. 10-13. (In Russian.)

23. Biktimirov R. A., Sharipkulova Z. M., Chanyshev I. O., Shakirzyanov A. Kh., Safin Kh. M., Leont'yev I. P. Sovremennaya tekhnologiya vozdelyvaniya sudanskoy travy v Respublike Bashkortostan [Modern cultivation technology of Sudan grass in the Republic of Bashkortostan]. Ufa : Mir pechati, 2019. 58 p. (In Russian.)

24. Singh V., Nguyen C. T., Yang Z., Chapman S. C., van Oosterom E. J., Hammer G. L. Genotypic Differences in Effects of Short Episodes of High-Temperature Stress during Reproductive Development in Sorghum // Crop Science Society of America. 2016. Vol. 56. Pp. 1561-1572. DOI: 10.2135/cropsci2015.09.0545.

25. Dospekhov B. A. Metodika polevogo opyta (s osnovami statisticheskoy obrabotki rezul'tatov issledovaniy) [Methodology of a field trial (with the basis of statistic processing of study results)]. The $5^{\text {th }}$ edition, rewritten and added. Moscow : Alyans, 2014. 351 p. (In Russian.)

26. Metodika gosudarstvennogo sortoispytaniya sel'skokhoziaistvennykh kul'tur [State methodology for crop variety testing]. Moscow, 1989. 250 p. (In Russian.)

\section{Authors' information:}

Rifkhat A. Biktimirov ${ }^{1}$, candidate of agricultural sciences, head of the forage crop breeding and seed production laboratory, leading researcher, ORCID 0000-0001-7800-9521, AuthorID 158709; +7 906 376-13-70, biktimirov.rifx@yandex.ru

Zulfira M. Sharipkulova ${ }^{1}$, chief agronomist of the forage crop breeding and seed production laboratory,

ORCID 0000-0002-4788-7353, AuthorID 611923; +7 927 088-57-45

Asiia A. Nizaeva ${ }^{1}$, chief agronomist, head of the forage production department, ORCID 0000-0002-1936-2204,

AuthorID 994019; +7 927 343-06-48,nizaeva_a@mail.ru

${ }^{1}$ Bashkir Research Institute of Agriculture - Subdivision of the Ufa Federal Research Center of the Russian Academy of Sciences, Ufa, Russia 